\title{
Physico-Chemical Characterization in Irrigated and Rainfed Agricultural Soils of Sidhi District, M.P
}

\author{
BIJENDRA KUMAR $^{1 *}$, ANSHUMALI ${ }^{2}$, KRITI SHUKLA $^{3}$, \\ ASMAA NAAZ ${ }^{4}$ and CHANDRAVIR NARAYAN ${ }^{5}$
}

\author{
Department of Environmental Science and Engineering, \\ Indian School of Mines, Dhanbad-826004, Jharkhand, India.
}

http://dx.doi.org/10.12944/CWE.9.3.52

(Received: November 12, 2014; Accepted: November 24, 2014)

\begin{abstract}
The Sidhi District is situated on the North-eastern boundary of the Madhya Pradesh State, India which lies over a transitional area between the Indo-Gangetic plain in the north and the Deccan plateau in the south and the remotest district of Madhya Pradesh The systemic and comprehensive analysis of twenty composite samples of rainfed and irrigated agricultural soil around Sidhi district. The $\mathrm{pH}$ of soil samples varied from 6.6 to 8 especially and recorded higher values in the irrigated soils. The EC and CEC showed large spatial variation in the irrigated soils. The results showed alterations in the biogeochemical relationships between physico-chemical parameters. In rain fed areas, the high $\mathrm{Si} / \mathrm{Al}$ and low $\mathrm{Fe} / \mathrm{Al}$ ratios showed silicate nature of agricultural soils along with low iron loss from primary silicates.
\end{abstract}

Key words: Agricultural, Soil texture, Irrigation, Rainfed.

\section{INTRODUCTION}

The Sidhi District is situated on the Northeastern boundary of the Madhya Pradesh State, India which lies over a transitional area between the Indo-Gangetic plain in the north and the Deccan plateau in the south and the remotest district of Madhya Pradesh. Soil is one of the important and valuable resources of the nature. All living things are directly and indirectly dependent on soil for day to day needs and $95 \%$ of the human food is derived from the earth. Making plan for having healthy and productive soil is essential to human survival. Soil is a natural body consisting of layers (soil horizons) of mineral constituents of variable thicknesses, which differ from the parent materials in their morphological, physical, chemical and mineralogical characteristics. Soil is composed of particles of broken rock that have been altered by chemical and mechanical processes that include weathering and erosion. Soil has complex function which is beneficial to human and other living organism. It acts as a filter, buffer storage, transformation system and thus protects the global ecosystem against the adverse effects of environmental pollutants. Environmental neglect by society, since the dawn of the industrial revolution has resulted in severe contamination of soil and water resources (Ramaswamy et al., 2007). Soil formation is a constructive as well as destructive process (Pujaret.al., 2012) the predominant destructive process are physical and chemical breaking down of materials, plants and animal structures which result in the partial loss of more soluble and volatile products. Soil types are a major factor in determining what types of plants will grow. The nature of soil primarily depend upon its continued change under the effect of physical factors like the parent material, time, the climate, the organic activity in it etc. (Solanki and Chavda, 2012). Although all physico-chemical properties are involved in soil functioning, bio chemical properties tend to react most rapidly to get change in the external environment (Nannipieriet al, 1990; Trasar-Cepeda et al, 2008). The soils of the study area comprised of Mollisol, Alfisols, Entisols, Inceptisols and Vertisol with alluvial, red and black soil types. The quality of parent material prevents 
the transformation of smectite to kaolin, helps in the retention of adequate amount of smectite and provides a continuous supply of bases ( $\mathrm{Ca}^{2+}$ ions) required for the formation of Mollisols. In the irrigated regions, soils were deep to medium deep black soils; while rainfed soils were characterized by red loamy soils. Crop yields everywhere in the developing world are consistently higher in irrigated areas than in rainfed areas (Hussain and Hanjra, 2004). About 17\% of global agricultural land is irrigated contributing about $40 \%$ to the world's production of cereal crops (WCD, 2000). In India, approximately $48.3 \%$ of cultivated area is under proper irrigation which gives rise to 234.4 million-tons of total agricultural production whereas about $60 \%$ of the total net sown area comes under rain-fed lands and its crop accounts for $48 \%$ under food crops. Irrigation and modern agricultural practices secure crop production at the cost of alterations in the soil characteristics, mainly in arid and semi-arid regions (Assis et al., 2010). The purpose of present study is to provide systematic and comprehensive analysis of rainfed and irrigated soils. This type of study is not previously done in the study area so this study may be useful for farmers. Information regarding some element in the agricultural soil may also be useful.

\section{MATERIALS AND METHODS}

\section{Study area}

The Sidhi District is situated on the Northeastern boundary (between $2247.5^{\prime}$ and 24 42.10' North latitude and $8118.40^{\prime}$ and 82 48.30' East

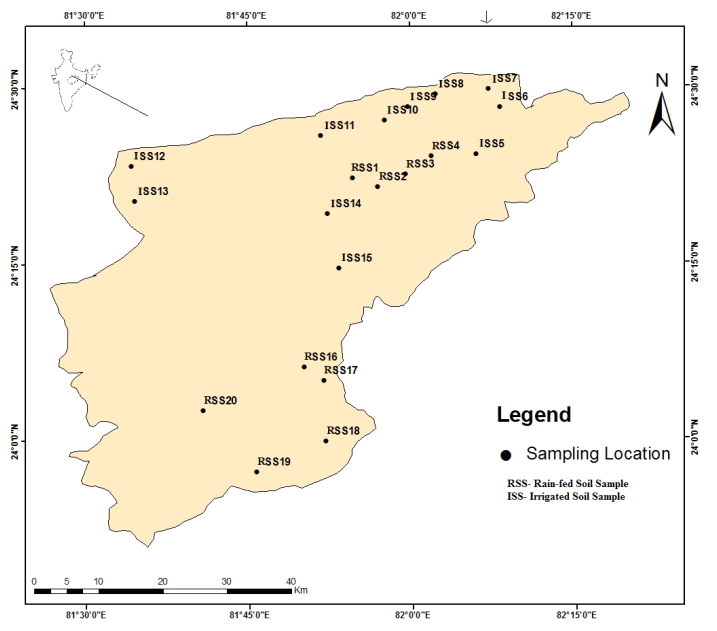

Fig. 1: Map of study area showing sampling locations latitude) of the Madhya Pradesh State, India which lies over a transitional area between the IndoGangetic plain in the north and the Deccan plateau in the south (Fig. 1). The physiography is characterized by low hill, extensive plateaus and Son river valley which is a depository of the Gondwana rocks. Topographically the district can be divided into three zones, Vindhyan hills or Kaimour range, Gondwana zone and Archean zone. Clay minerals like kaolinite, halloysite, diaspore, gibbsite, nacrite, and dicktite etc. are derived by the localized weathering of arkosic metasediments (Mehrotra et al., 1979). The average elevation of the area is $311 \mathrm{~m}$ above MSL. The climate of the area is tropical monsoon type with three distinct seasons as hot and dry summer (March-June), monsoon (July-September), and winter (November - February). The average annual rainfall varies from 1000-1200 mm, peaks in the months of July and August. The total population of the area is 1.12 million spread with a density of $110 / \mathrm{km}^{2}$ (Census, 2011). The total land covered in the Sidhi district is $10,536 \mathrm{~km}^{2}$ in which the forest area covers $40 \%$. The portion of the land used for agricultural purpose is $47 \%$ but only $17 \%(66,800 \mathrm{ha})$ of the land used for agricultural purpose has assured supply of irrigation and the rest of the agricultural land ( $413500 \mathrm{ha})$ is dependent on rainfed irrigation and produces only one crop a year (NRAA, 2012). The major irrigation sources are tube wells $(26,500$ ha), canals (12,800 ha) and wells (11000 ha), and other sources (16,500 ha). The land is largely undulating terrain, which often has steep gradients not ideal for cultivation; the valleys along the major rivers like the Son and the Gopad have fertile soils. The crops grown are rice, maize, barley, pigeon pea and jute in Kharif season, and wheat, mustard

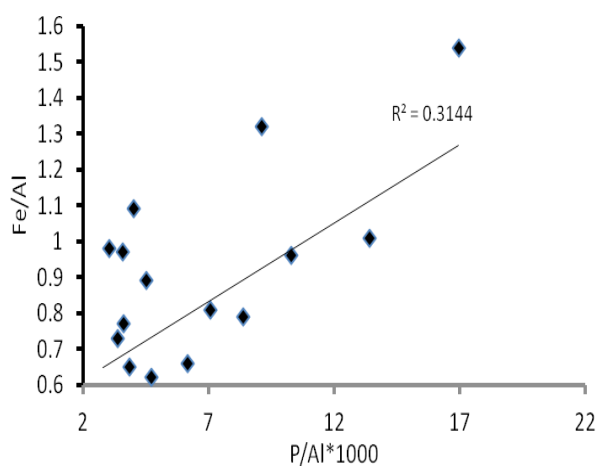

Fig. 2: Linear relationship between P/Al ${ }^{\star} 1000$ versus Fe/Al 


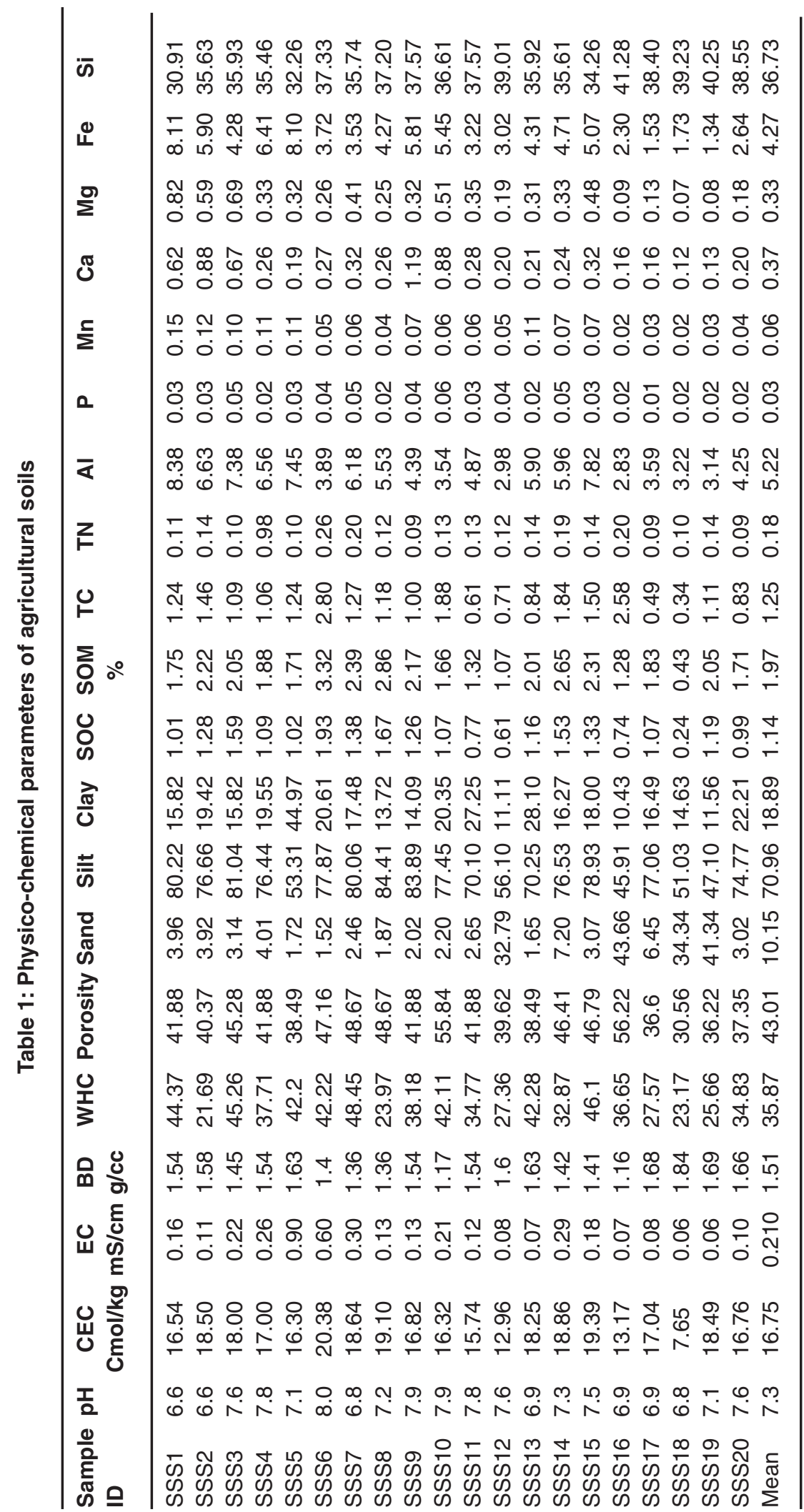


and lentil in Rabi season. The natural vegetation comprises tropical dry deciduous forests.

\section{Field survey and sample collection}

Twenty soil samples (0-20 cm depth) were collected from agricultural lands (Table 1) cultivated by modern tools and techniques in the catchment of Son and Gopad rivers, and traditional techniques in the rainfed, hilly and forest areas (Fig. 1). In each field, a plot of one hectare was selected and five soil cores ( $5 \mathrm{~cm}$ inner diameter each) of 0-20 cm depth were randomly sampled from five points (north, south, east, west and central) and mixed to obtain a composite sample. The sampling was carried out in the dry summer season (June 2013). The all soil samples were stored in acid-cleaned HDPE bottles in frozen state using portable ice box to minimize the biogeochemical alterations and transported to the laboratory for analytical processing. All soil samples were air-dried, crushed by wooden stick and the gravel and relict bodies were picked out.

\section{Laboratory analysis}

The $\mathrm{pH}$ and electrical conductivity (EC) were measured on 1:2.5 and 1:5 soil: water (w/v) ratio, respectively (Allison and Moodie, 1965); bulk density (BD) was analysed by Core method (Blake, 1965); water holding capacity (WHC) was determined by keeping fresh soil overnight with water at a 1:2 ratio (Harding and Ross (1964); soil organic carbon and organic matter content was determined by the Walkley and Black dichromate oxidation method (Nelson and Sommers, 1982); the cation exchange capacity (CEC) by ammonium acetate method. The total carbon (TC) and total nitrogen (TN) by Elemental Analyser (Thermo Flash 2000) The elements (Al, Fe, Ca, Mg, Mn, and $P$ ) were analysed by the ICP-OES (Leeman Profile Plus) at NMDC, Donimalai, Karnataka. The particle size analysis was carried out by Microtrac S3500 analyzer in Jawaharlal Nehru University, New Delhi. To evaluate the potential relationship between various physiochemical parameters, factor analysis were carried out by using "Statistical Package for Social Sciences (SPSS), version-10.0". "Principal component analysis" and "Varimax Rotation" was used for extraction and deriving factors, respectively

\section{RESULTS AND DISCUSSION}

Table-1 presents the results of physicochemical parameters of agricultural soils of the Sidhi district. The $\mathrm{pH}$ of soil samples varied from 6.6 to 8 especially and recorded higher values in the irrigated soils. The EC and CEC showed large spatial variation in the irrigated soils. The SOC and SOM showed significant spatial variations. The elemental concentrations were found below the average earth crust values. Particle size analysis of soil samples showed a diversified range of sand, silt and clay with silt as the most dominating fraction. The bulk density did not show any trend and recorded high in both, irrigated and rain-fed agricultural soils. In the irrigated system, the greater soil bulk density might be due to the combined influence of greater wheel traffic (Carter et., 1998) and decrease in soil total organic carbon and soil aggregation (Celik, 2005) as a result of repeated events of sawing and harvesting (Li et al., 2007). The mean value of TC and TN were $1.25 \%$ and $0.18 \%$ respectively. The $\mathrm{C}: \mathrm{N}$ ratio varied from 1.08-14.46.

The Pearson correlation analysis reveals positive correlation of CEC with silt, SOC and $\mathrm{SOM}$, and silt showed positive correlation with $\mathrm{Si}$, SOC, SOM, Ca and Mg. This infers that the CEC is determined by inorganic and organic constitutes of soils (Table 2). The positive relationship between Al and $\mathrm{Fe}, \mathrm{Al}$ and $\mathrm{Mg}, \mathrm{Al}$ and $\mathrm{Mn}, \mathrm{Fe}$ and $\mathrm{Mg}, \mathrm{Fe}$ and $\mathrm{Mn}$ indicate their similar sources and cation exchange reactions in highly weathered soils is regulated by dominance of oxy-hydroxides of $\mathrm{Al}, \mathrm{Fe}$ and $\mathrm{Mn}$.

The positive statistical relationship between $\mathrm{P} / \mathrm{Al}$ and $\mathrm{Fe} / \mathrm{Al}$ (Fig.2) indicates that the authigenic iron oxy-hydroxides have a high capacity to adsorbed phosphorus onto their surface (Likjlema, 1980). Thus, precipitation and accumulation of authigenic iron-oxides causes a corresponding increase in $\mathrm{P} / \mathrm{Al}$ and $\mathrm{Fe} / \mathrm{Al}$ and seem to be the main process explaining the global variability observed in the agricultural soils. This reflects that the increase of phosphate concentration over the back ground composition is linked with the increase in iron across the same background material. 


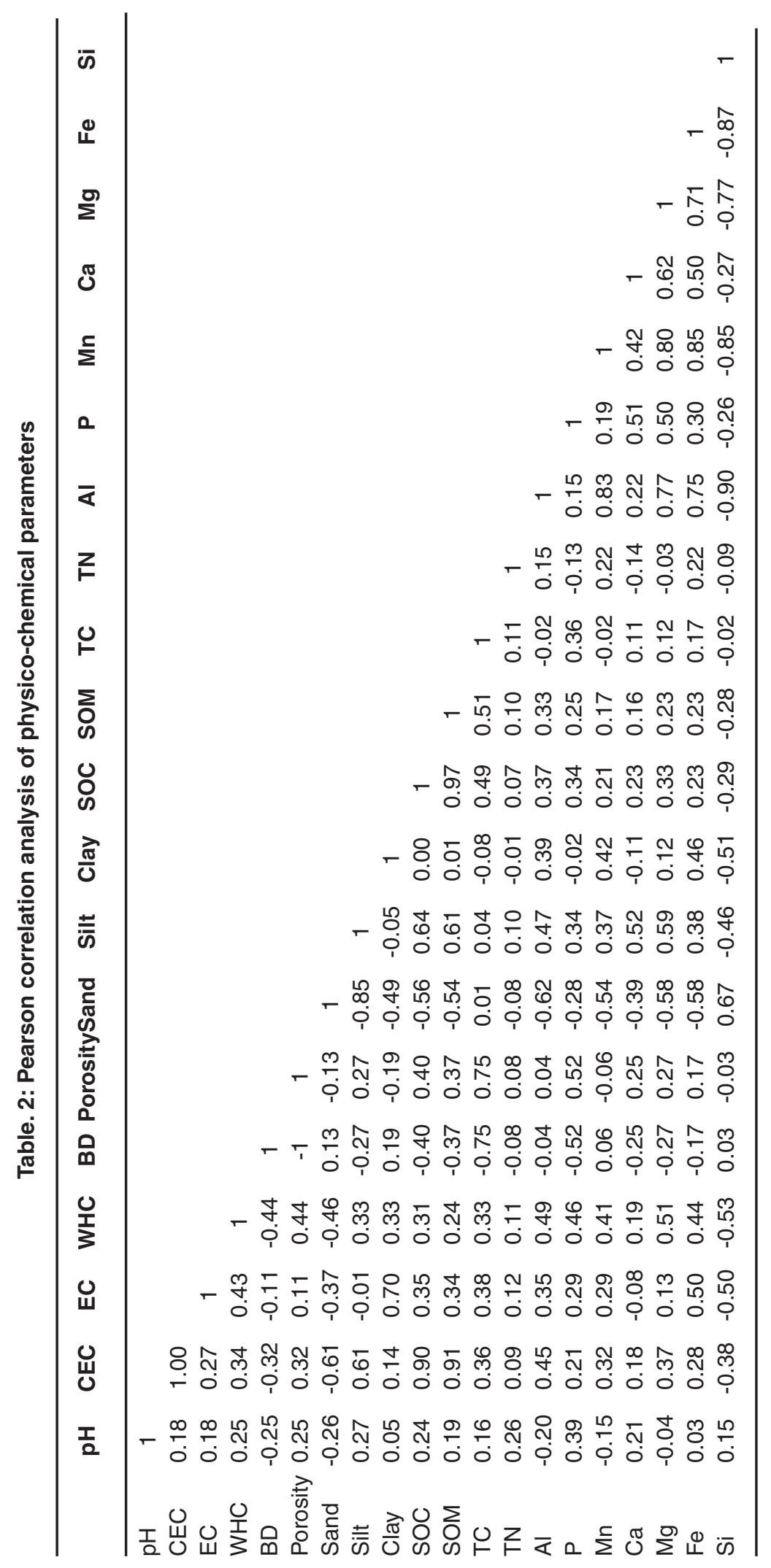




\section{CONCLUSIONS}

The physico-chemical parameters show spatial variation in cropping pattern, mode of irrigation, mechanical farming, soil texture etc. The silty loam texture and geochemical ratios show the dominance of clay minerals in the irrigated soils. The low Si/Al ratio and high Fe/Al ratio show high mobility or non-silicate nature of agricultural soils cultivated under double cropping system. The elemental concentrations were found below the average earth crust values. In the irrigated system, the greater soil bulk density might be due to the combined influence of greater wheel traffic. The decreasing trend of soil total organic carbon and soil aggregation as a result of repeated events of sawing and harvesting
The Pearson correlation analysis reveals positive correlation of CEC with silt, SOC and SOM, and silt showed positive correlation with $\mathrm{Si}, \mathrm{SOC}, \mathrm{SOM}, \mathrm{Ca}$ and $\mathrm{Mg}$. This infers that the CEC is determined by inorganic and organic constitutes of soils.

\section{ACKNOWLEDGEMENTS}

The authors thank the Ministry of Human Resource Development, Government of India for funding the research work. We are also grateful to the Department of Environmental Science and Engineering, Indian School of Mines, Dhanbad for providing the logistic support to carry out field monitoring and laboratory analysis.

\section{REFERENCES}

1. Assis, C. P., Oliveira, T. S., Nbrega Dantas, J. A. and Mendonca, E. Organic matter and phosphorus fractions in irrigated agroecosystems in a semi-arid region of Northeastern Brazil. Agriculture, Ecosystem and Environment 138, 74-82 (2010)

2. Carter, M. R., Greorich, E. G., Angers, D. A., Donald, R. G. and Bolinder, M. A. Organic C and $\mathrm{N}$ storage, organic $\mathrm{C}$ fractions in adjacent cultivated and forested soils of eastern Canada. Soil and Tillage Research 47, 253261 (1998)

3. Blake, G. R. Bulk Density in Methods of Soil Analysis. Agronomy, C. A. Black, (Ed.) 9 (11): 374-390 (1965).

4. Celik, I. Land-use effects on organic matter and physical properties of soils in a southern Mediterranean highland of Turkey. Soil \& Tillage Research 83, 270-277 (2005)

5. Census of India, Provisional population totals, Ministry of Home Affairs, Government of India (2011)

6. Harding, D. E., Ross, D. J. Some factors in low-temperature storage influencing the mineralisable-nitrogen of soils. J. Sci. Food Agric. 15: 829-834 (1964).

7. Hussain, I., and Hanjra, M. A. Irrigation and poverty alleviation: review of the empirical evidence. Irrigation and Drainage 53, 1-15 (2004).

8. Li, X. G., Li, F. M., Zed, R., Zhan, Z. Y. and Singh, B. Soil physical properties and their realtions to organic carbon pools as affected by land-use in an alpine pastureland. Geoderma 139, 98-105 (2007).

9. Likjlema, L. Interaction of orthophosphate with iron III and aluminium hydroxides. Environmental Science \& Technology 14, 537-541 (1980)

10. National Rainfed Area Authority (NRAA) Prioritization of rainfed areas in India. Study Report 4, Planning Commission, Government of India, New Delhi (2012)

11. Nannipieri, P. Ceccanti, B. and Grego, S. Ecological significance of biological activity in Soil. Soil Biochemistry, Vol.6 Marcel Dekker, New York, 293-355 (1990):

12. Nelson, D.W. and Sommers, L. E. Total carbon, organic carbon and organic matter. In: Page Miller, A. L. Keeney, R.H. (eds.), Methods of Soil Analysis. Part 2. $2^{\text {nd }}$ ed. American Society of Agronomy-Soil Science Society of America, Madison, WI, pp. 539-580 (1982).

13. Peng, J. F., Wang, B. Z., Song, Y. H., Yuan, P. and Liu, Z. Adsorption and release of phosphorus in the surface sediment of a wastewater stabilization pond. Ecological Enggineering 31, 92-97 (2007)

14. Pujar K. G., Hiremath S. C., Pujar A. S., Pujeri U. S. and Yadawe M. S., Analysis of PhysicoChemical and Heavy Metal Concentration in Soil of BijapurTaluka, Karnataka Sci. Revs. 
Chem. Commun. 2(1),: 76-79 (2012)

15. Qiong, Z., De-Hui, Z., Zhi-Ping, F. and Lee, D. K. Effect of land cover change on soil phosphorus fractions in Southeastern Horqin Sandy Land, Northern China. Pedosphere 18(6), 741-74 (2008)

16. Ramaswamy, V., V. M. Cresence, J. S. Rejitha, M. U. Lekshmi, K. S. Dharsana, S. P. Prasad, and H. M. Vijila. "Listeria: Review of Epidemiology and Pathogenesis." Journal of Microbiology, Immunology, and Infection 40: 4-13 (2007).

17. Solanki,H.A.and Chavda,N. H. Physico chemical analysis with reference to seasonal changes in soils of Victoria park reserve forest, Bhavnagar (Gujarat). Life sciences Leaflets. 8, 62-68 (2012)

18. Trasar-Cepeda, C., Leirós, M. C., Gil-Sotres, F., Hydrolityc enzyme activities in agricultural and forest soils. Some implications for their use as indicators of soil quality. Soil Biology and Biochemistry, 40: 2146-2155 (2008)

19. World Commission on Dams (WCD) Dams and Development: A New Framework for Decision-making. London, UK: Earthscan Publishers (2000) 